\title{
Revisiting the Birth of 7YSZ Thermal Barrier Coatings: Stephan Stecura ${ }^{\dagger}$
}

\author{
James L. Smialek ${ }^{1, *(1)}$ and Robert A. Miller ${ }^{2}$ \\ 1 National Aeronautics and Space Administration, Glenn Research Center, Cleveland, OH 44135, USA \\ 2 Vantage Partners, LLC, Brook Park, OH 44142, USA; robert.a.miller@nasa.gov \\ * Correspondence: james.l.smialek@nasa.gov \\ + Dr. Stephan Stecura emigrated to the US from Ukraine, worked on high temperature materials at NASA \\ Glenn from about 1966, retired in 1994, and lives in the greater Cleveland area. He was well known for his \\ discerning, enigmatic approach to research and the smile on his face and treasure troves of original data \\ tucked away in notebooks. The authors are fortunate to have witnessed and studied his successes.
}

Received: 6 July 2018; Accepted: 20 July 2018; Published: 22 July 2018

check for Abstract: Thermal barrier coatings are widely used in all turbine engines, typically using a $7 \mathrm{wt} . \%$
$\mathrm{Y}_{2} \mathrm{O}_{3}-\mathrm{ZrO}_{2}$ formulation. Extensive research and development over many decades have refined the
processing and structure of these coatings for increased durability and reliability. New compositions
demonstrate some unique advantages and are gaining in application. However, the "7YSZ"
(7 wt.\% yttria stabilized zirconia) formulation predominates and is still in widespread use. This special
composition has been universally found to produce nanoscale precipitates of metastable t' tetragonal
phase, giving rise to a unique toughening mechanism via ferro-elastic switching under stress.
This note recalls the original study that identified superior properties of $6-8 \mathrm{wt} . \%$ yttria stabilized
zirconia (YSZ) plasma sprayed thermal barrier coatings, published in 1978 . The impact of this
discovery, arguably, continues in some form to this day. At one point, $7 \mathrm{YSZ}$ thermal barrier coatings
were used in every new aircraft and ground power turbine engine produced worldwide. 7YSZ is
a tribute to its inventor, Dr. Stephan Stecura, NASA retiree.

Keywords: thermal barrier coatings; 7YSZ; turbine blades

\section{Background}

Yttria stabilized zirconia (YSZ) thermal barrier coatings (TBC) are widely used in turbine engines to protect underlying metal structures from the intense heat of combusted jet fuel. The standard industry composition is $7 \mathrm{wt} . \% \mathrm{Y}_{2} \mathrm{O}_{3}-\mathrm{ZrO}_{2}$. It has been estimated that industry capital expenditures for finished YSZ thermal barrier aerospace coatings reached $\$ 1500 \mathrm{M}$, just for 2015 alone [1], with 1-2 Mkg of YSZ used for plasma sprayed coatings [2]. Indeed, a Google search on the exact phrase "YSZ Thermal Barrier Coatings for Aircraft Engines" provided 35,800 hits from all sources, indicating the high level of general interest.

The early years, around 1970 and before, saw increasing interest and trials of air plasma sprayed (APS) oxides and fully stabilized zirconia $\left(\sim 12 \mathrm{wt} . \% \mathrm{Y}_{2} \mathrm{O}_{3}\right)$ as thermal barriers for hot components in general [3-5]. However, use in critical aircraft components was restricted because of limited cyclic lifetime: the coatings had a propensity to spall from compressive thermal stress, aggravated by the oxidation of underlying substrates or bond coats.

\section{Seminal Experimental Findings}

Fully stabilized zirconia, using $\mathrm{MgO}, \mathrm{CaO}$, or $\mathrm{Y}_{2} \mathrm{O}_{3}$ to stabilize the cubic phase of $\mathrm{ZrO}_{2}$, had become fairly standard practice by the early 1970s. $\mathrm{Y}_{2} \mathrm{O}_{3}$ provided more long term durability than 
the other stabilizers that tended to volatilize, hydrate, and destabilize the cubic phase. Compositional studies of YSZ were minimal and simply recommended high $\mathrm{Y}_{2} \mathrm{O}_{3}$ cubic phases. However, one enabling discovery for present day TBCs came when partially stabilized (tetragonal) zirconia was first identified as more resistant to thermal cycling than fully stabilized cubic zirconia [6,7]. The kernel of the results from an extensive plasma spray TBC system optimization [6] is provided in Figure 1. The optimal 6-8 wt.\% YSZ composition was confirmed in furnace, natural gas/oxygen torch, and Mach 1 jet fueled burner rig tests (using actual air cooled PWA (Pratt and Whitney Aircraft) J75 (JT4A) turbine blades), totaling about 75 sample conditions overall, most with duplicates. This screening study was one in a series of developmental TBC studies [8].

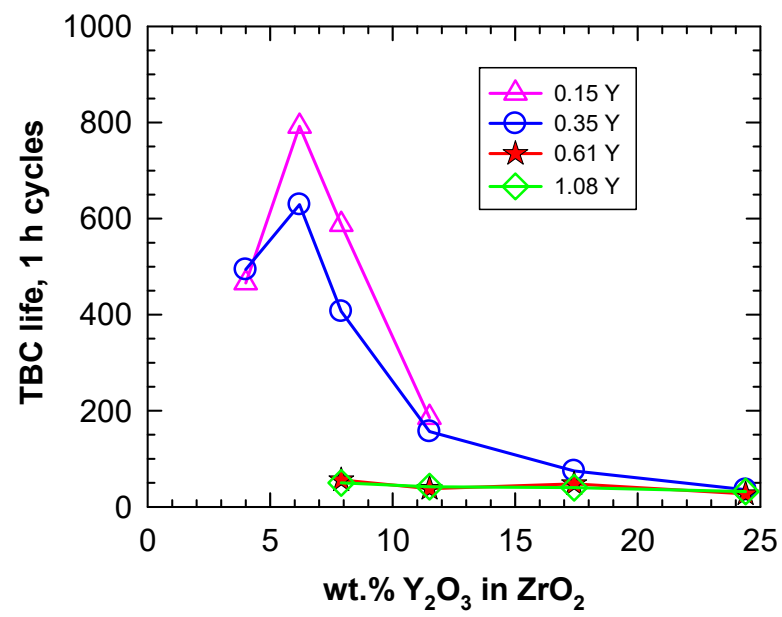

Figure 1. Thermal barrier coatings (TBC) life (time to first TBC crack) in $1200{ }^{\circ} \mathrm{C} 1$-h cyclic natural gas- $\mathrm{O}_{2}$ torch rig test of air plasma sprayed (APS) yttria stabilized zirconia (YSZ) as a function of $\mathrm{Y}_{2} \mathrm{O}_{3}$ content in YSZ for four Ni-16Cr-5Al-Y bond coats [6] (also presented in [9]).

Pertinent conclusions were summarized as: "The data indicate that the best thermal barrier systems consisted of combinations involving the Ni-16.4Cr-5.1Al-0.15Y and $\mathrm{Ni}-17.0 \mathrm{Cr}-5.4 \mathrm{Al}-0.35 \mathrm{Y}$ bond coatings and the $6.2 \mathrm{Y}_{2} \mathrm{O}_{3}-\mathrm{ZrO}_{2}$ and $7.9 \mathrm{Y}_{2} \mathrm{O}_{3}-\mathrm{ZrO}_{2}$ stabilized zirconium oxide layers (all in wt.\%)." Furthermore, testifying to the durability on air-cooled blades: " . . at 1580 and $1550{ }^{\circ} \mathrm{C}$ surface temperatures, withstood 1300 and 1500 1-h cycles without failure, respectively. In the Mach 1.0 burner rig the above two systems withstood over 1400 and 2000 1-h-cycles without failure at about 1480 and $1470{ }^{\circ} \mathrm{C}$ surface temperatures, respectively" (temperatures subject to pyrometric uncertainty).

Similar trends were confirmed in a subsequent optimization study, as illustrated in Figure 2. Here, coated coupons were tested in cyclic furnace tests until the first visible crack in the TBC. The bond coat for this series was the optimized $\sim \mathrm{Ni}-16 \mathrm{Cr}-6 \mathrm{Al}-0.17 \mathrm{Y}$ and achieved a maximum life near 400 cycles. Greater lives approaching 1400 cycles were produced with another bond coat having a $\sim \mathrm{Ni}-35 \mathrm{Cr}-6 \mathrm{Al}-1.0 \mathrm{Y}$ composition, with presumably a lower coefficient of thermal expansion (CTE) because of $\alpha$-Cr precipitates. The success of YSZ coatings was highly leveraged by numerous concurrent plasma sprayed TBC studies at NASA Glenn (nee Lewis) Research Center, most notably component and engine tests championed by Curt Liebert as far back as 1972 [2,3,7,8,10-12]. No comparable studies of bulk $\mathrm{Y}_{2} \mathrm{O}_{3}-\mathrm{ZrO}_{2}$ properties existed at the time, although the phase diagram of Scott did identify the metastable tetragonal phase in that range. 


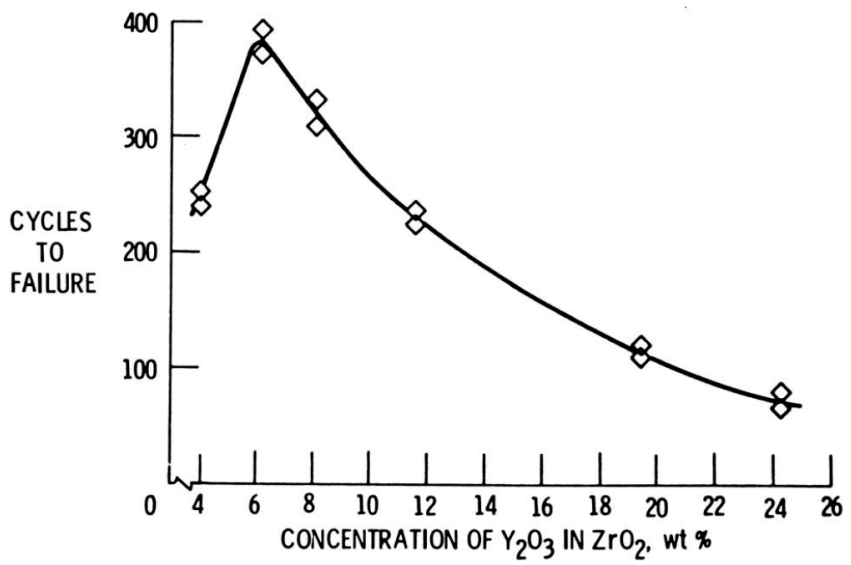

Figure 2. TBC life (time to first $\mathrm{TBC}$ crack) in $1110{ }^{\circ} \mathrm{C}$ 1-h cyclic furnace test as a function of $\mathrm{Y}_{2} \mathrm{O}_{3}$ content in YSZ; Ni-16Cr-6Al-0.2Y bondcoat [13].

\section{Growing Interest and Impact}

An indication of the level of world-wide interest in yttria-stabilized zirconia (YSZ) thermal barrier coatings can be surmised from internet searches of journal articles using Google Scholar. In the 1970-1985 timeframe, there were only about 18 related articles in standard materials science journals that followed YSZ TBC research, Table 1. They were predominately in Thin Solid Films. In the next five years Surface and Coatings Technology led with 19 articles. Finally, over the last 25 years, YSZ coating articles in just the Surface and Coatings Technology journal alone burgeoned to nearly 650 . Contributions in the journals listed totaled 2500 YSZ coating articles from 1990-2016. A simple Google search yielded about 7000 hits from all sources (bottom row). The early "yttria-stabilized zirconia thermal barrier coating" items outside the journals were primarily NASA and other government agency reports or society proceedings [14]. Clearly, the YSZ thermal barrier industry has grown exponentially, with most contributions after 1990, and with the successful $\sim 7 \mathrm{wt} . \%$ yttria stabilized zirconia ( 7YSZ) composition as the most prevalent composition. A case can be made that the success of optimal 7YSZ TBC coatings led to that composition being adopted for other applications, such as oxygen conductors in sensors or fuel cells.

Table 1. Google Scholar hits for all words (YSZ thermal barrier coatings) anywhere in journal articles. Last row indicates hits for any source using search term YSZ and exact term "thermal barrier coating".

\begin{tabular}{cccc}
\hline \multirow{2}{*}{ Google Scholar Searches } & \multicolumn{3}{c}{ Term: YSZ Thermal Barrier Coatings } \\
\cline { 2 - 4 } & $\mathbf{1 9 7 0 - 1 9 8 5}$ & $\mathbf{1 9 8 5 - 1 9 9 0}$ & $\mathbf{1 9 9 0 - 2 0 1 6}$ \\
\hline Surface and Coatings Technology & 0 & 19 & 648 \\
Journal of Thermal Spray Technology & 0 & 0 & 483 \\
Journal of American Ceramic Society & 0 & 0 & 429 \\
Ceramics International & 1 & 0 & 355 \\
Journal of European Ceramic Society & 0 & 0 & 285 \\
Thin Solid Films & 17 & 0 & 99 \\
Acta Materialia & 0 & 0 & 146 \\
Scripta Materialia & 0 & 27 & 48 \\
(select journals) total & 18 & 183 & 2493 \\
all sources (+patents) & 181 & & 6940 \\
\hline
\end{tabular}

\section{More Compositional Details and Overall Context}

An overview of the mechanisms, complexity, and critical refinements to achieve this growth can be appreciated from a number of key contributions and reviews, offered chronologically in the closing bibliography $[5,9,15-21]$. Many of these and current topics of high interest were covered in the 2012 topical issue of the MRS Bulletin [2,22-25]. While these represent only a fraction of the 
pertinent literature, virtually all refer to "7YSZ" or "6-8 wt. $\% \mathrm{Y}_{2} \mathrm{O}_{3}-\mathrm{ZrO}_{2}$ " as the standard TBC topcoat composition, essentially unchanged from its original discovery in 1978.

The attributes of the 1978 study believed to be key to identifying the preferred 6-8 wt.\% YSZ performance were experimental thoroughness and process control for what was then basically a hand spray process. The consistent life data is a tribute to the long-time skilled APS operator, Jack E. Brown, under the watchful direction of Dr. Stecura. Consistent bond coat and top coat thicknesses were obtained, necessitating frequent measurements during processing. Care was taken to apply APS bond and top coats within minutes of pre-conditioning by a light grit blasting to improve bonding and avoid uncontrolled random variations by ambient humidity and native oxide effects.

The composition of the Ni-16Cr-5Al-Y bond coat represented the then current range for optimal alumina scale formation and ductility consistent with results on bulk alloys provided by the oxidation literature at that time. The Y-dopant level was varied at $0.15,0.35,0.61$, and $1.08 \mathrm{wt} . \%$. Initially, the best lives were obtained for Ni-16Cr-5Al at the 0.15 and $0.35 \mathrm{wt} . \% \mathrm{Y}$ levels, which allowed the full cyclic life of the TBC to be realized. High Y levels are generally needed in air plasma spray compared to physical vapor deposition (PVD) or bulk alloys because some of the $\mathrm{Y}$ is oxidized during spraying, thus diminishing $\mathrm{Y}$ in solution. Too high a level results in $\mathrm{YNi}_{9}$ precipitates and disruptive oxidation behavior in those regions. None of the more robust alumina scale adhesion (sulfur-gettering) theories accepted today were even thought of at that time, but empirical results had indicated this strong sensitivity to low levels of $Y$ dopants.

The $\mathrm{Y}_{2} \mathrm{O}_{3}$ content of the $\mathrm{ZrO}_{2}$ was varied at 4.0, 6.2, 7.9, 11.5, 17.4, and 24.4 wt. $\% \mathrm{Y}_{2} \mathrm{O}_{3}-\mathrm{ZrO}_{2}$. At that time, the $t^{\prime}$ metastable tetragonal was not identified in YSZ coatings until Miller (1981), so there was no specific rationale for the optimal behavior (except avoidance of the metastable tetragonal t-phase in lower Y coatings that disruptively transforms to monoclinic after cycling). It is now well known that the optimal behavior of 7YSZ derives from the formation of the $t^{\prime}$ phase that does not transform martensitically to the monoclinic $\mathrm{ZrO}_{2}$ phase on cooling. Nor is it susceptible to the stress-induced transformation toughening that had been popular at the time in coining the term "ceramic steel". Since it does not transform to monoclinic upon deformation (stress-induced), it was originally termed "non-transformable" tetragonal in Miller, et al. [7]. Initially, the durability of 7YSZ corresponds to this slightly tetragonal $t^{\prime}$ phase, as fine precipitates have three possible orientation relationships to the parent cubic [7,26-28]. Ultimately it was shown that ferro-elastic switching on a nanoscale can explain the toughening mechanism for $7 \mathrm{YSZ}$ and its superior performance $[29,30]$. The failure locus was originally identified as a crack in the YSZ layer near the bond coat, essentially the same as current APS failure descriptions.

\section{The Aftermath: Processing, Understanding, and the Future}

These features, i.e., the $t^{\prime}$ YSZ phase and an oxidation resistant MCrAlY bond coat, provided the starting point for highly durable coatings. Stecura's additional improvements to these early APS coatings revolved around high 25-35 wt.\% Cr, Yb-doped MCrAl bond coats [31] and 12-15 wt.\% $\mathrm{Yb}_{2} \mathrm{O}_{3}-\mathrm{ZrO}_{2}$ top coats [32]. However, the interest and improvements in $7 \mathrm{YSZ}$ based TBC systems continues to this day. The most notable contribution is the EB-PVD (electron beam-physical vapor deposition) coating processing for strain tolerance and aerodynamically smooth airfoil surfaces. Also, robotic APS topcoat deposition, low pressure plasma spray (LPPS) MCrAlY, and CVD processing of $\mathrm{Ni}(\mathrm{Pt}) \mathrm{Al}$ bond coats have all improved durability and increased use. Oxidative failure mechanisms have enhanced understanding, with finite element models showing CTE mismatch stress concentrations at asperities in plasma sprayed MCrAlY. Oxidatively ratcheted alumina scales (thermal grown oxide, TGO) and ridged or rumpled $\mathrm{Ni}(\mathrm{Pt}) \mathrm{Al}$ bond coats cause stress concentrations and failure upon cycling. Thermal gradients and sintering of the YSZ have been used to refine failure models, especially in high heat flux laser tests.

Compositionally, low $\mathrm{SiO}_{2}$, high purity YSZ is an initial prerequisite to minimize sintering and loss of compliance. Small particle plasma spray (SPS) and solution precursor plasma spray 
(SPPS) offer unique advantages in tailoring strain tolerant, low $k$ TBC microstructure or uniform composition of chemical modifications. Multiply-doped, low $k$, sinter- and calcium magnesium aluminosilicate (CMAS)-resistant $\mathrm{YbGd}$-doped cubic $\mathrm{YSZ}$ and $(\mathrm{La}, \mathrm{Gd})_{2} \mathrm{Zr}_{2} \mathrm{O}_{7}$ pyrochlores represent successful new directions in commercial TBC chemistry beyond 7YSZ [33]. All the advances mentioned above are covered in the aforementioned reviews and the details are beyond the scope of this simple memorandum.

\section{Conclusions}

The current dominance of the 7YSZ chemistry for coatings already in service can be directly traced to the original studies by Stecura. It is therefore a remarkable historical point that this empirically derived coating composition endures some 35 years later, with arguably a direct impact on current technology. Compared to other continually evolving turbine related material compositions over the same time frame, such as directionally solidified or single crystal nickel-base superalloys (gen 1-5), doped Pt-aluminide (+Hf, $\mathrm{Si}$, etc.) bond coats, and dual microstructure disk alloys, 7YSZ appears relatively unchanged from this 1978 study. 7YSZ has become so widely used now that the impact of the original finding, often lost in a background search, cannot be overemphasized and is a credit to its inventor. It is important to recognize that the discovery, prior to numerous subsequent advances in characterization and understanding, was accomplished by structured, well-informed empiricism coupled with experimental diligence.

Author Contributions: J.S. conceived the idea for this article, produced the citation research, and wrote the first draft. R.M. reviewed the article for technical accuracy and provided historical and global background for TBC development.

Funding: This research received no external funding.

Acknowledgments: The authors are grateful for long-standing support of TBC research through NASA Aeronautics Base programs and projects. The comments and encouragement from N. Padture and R. Darolia are appreciated. The marketing data was kindly provided by Santosh Nichani from Grandview Research.

Conflicts of Interest: The authors declare no conflict of interest.

\section{References}

1. Nichani, S.; Pillai, K.; Varma, J. Thermal Barrier Coatings Market Report. Available online: https://www. grandviewresearch.com (accessed on 20 December 2016).

2. Sampath, S.; Schulz, U.; Jarligo, M.O.; Kuroda, S. Processing science of advanced thermal-barrier systems. MRS Bull. 2012, 37, 903-910. [CrossRef]

3. Miller, R. Current status of thermal barrier coatings-An overview. Surf. Coat. Technol. 1987, 30, 1-11. [CrossRef]

4. Miller, R.A. Thermal barrier coatings for aircraft engines: History and directions. J. Therm. Spray Technol. 1995, 6, 35-42. [CrossRef]

5. Miller, R.A. History of Thermal Barrier Coatings for Gas Turbine Engines: Emphasizing NASA's Role From 1942 to 1990; NASA/TM-2009-215459; NASA Glenn Research Center: Cleveland, OH, USA, 2009.

6. Stecura, S. Effects of Compositional Changes on the Performance of a Thermal Barrier Coating System; NASA TM-78976; NASA Lewis Research Center: Cleveland, OH, USA, 1978.

7. Miller, R.A.; Smialek, J.L.; Garlick, R.G. Phase stability in plasma-sprayed partially stabilized zirconia-yttria. In Science and Technology of Zirconia; Heuer, A.H., Hobbs, L.W., Eds.; American Ceramic Society: Cleveland, OH, USA, 1981; Volume 3, pp. 242-253.

8. Stecura, S. Thermal Barrier Coating System. U.S. Patent 4,485,151, 27 November 1984.

9. Darolia, R. Thermal barrier coatings technology: Critical review, progress update, remaining challenges and prospects. Int. Mater. Rev. 2013, 58, 315-348. [CrossRef]

10. Stecura, S.; Liebert, C.H. Ceramic Thermal Protective Coating Withstands Hostile Environment of Rotating Turbine Blades; LEW-12554; NASA Lewis Research Center: Cleveland, OH, USA, 1975.

11. Stecura, S.; Liebert, C.H. Thermal Barrier Coating System. U.S. Patent 4,055,705, 25 October 1977. 
12. Liebert, C.H.; Jacobs, R.E.; Stecura, S.; Morse, C.R. Durability of Zirconia Thermal-Barrier Ceramic Coatings on Air-Cooled Turbine Blades in Cyclic Jet Engine Operation; NASA-TM-X-3410; NASA Lewis Research Center: Cleveland, OH, USA, 1976; p. 16.

13. Stecura, S. Optimization of the NiCrAl-Y/ZrO $2-Y_{2} \mathrm{O}_{3}$ Thermal Barrier; NASA-TM-86905; NASA Lewis Research Center: Cleveland, OH, USA, 1985.

14. Scientific and Technical Information Program. Available online: https:/ /www.sti.nasa.gov/ (accessed on 17 July 2018).

15. DeMasi-Marcin, J.T.; Sheffler, K.D.; Bose, S. Mechanisms of degradation and failure in a plasma-deposited thermal barrier coating. J. Eng. Gas Turbines Power. 1990, 112, 521-526. [CrossRef]

16. Evans, A.G.; Mumm, D.R.; Hutchinson, J.W.; Meier, G.H.; Pettit, F.S. Mechanisms controlling the durability of thermal barrier coatings. Prog. Mater. Sci. 2001, 46, 505-553. [CrossRef]

17. Padture, N.P.; Gell, M.; Jordan, E.H. Thermal barrier coatings for gas-turbine engine applications. Science 2002, 296, 280-284. [CrossRef] [PubMed]

18. Nicholls, J.R. Advances in coating design for high-performance gas turbines. MRS Bull. 2003, 28, 659-670. [CrossRef]

19. Bose, S. Thermal barrier coatings (TBCs). In High Temperature Coatings; Elsevier: Amsterdam, The Netherlands, 2007; pp. 155-232.

20. Strangman, T.; Raybould, D.; Jameel, A.; Baker, W. Damage mechanisms, life prediction, and development of EB-PVD thermal barrier coatings for turbine airfoils. Surf. Coat. Technol. 2007, 202, 658-664. [CrossRef]

21. Evans, H.E. Oxidation failure of TBC systems: An assessment of mechanisms. Surf. Coat. Technol. 2011, 206, 1512-1521. [CrossRef]

22. Clarke, D.R.; Oechsner, M.; Padture, N.P. Thermal-barrier coatings for more efficient gas-turbine engines. MRS Bull. 2012, 37, 891-898. [CrossRef]

23. Pan, W.; Phillpot, S.R.; Chunlei, W.; Chernatynskiy, A.; Qu, Z. Low thermal conductivity oxides. MRS Bull. 2012, 37, 917-921. [CrossRef]

24. Vassen, R.; Kagawa, Y.; Subramanian, R.; Zombo, P.; Zhu, D. Testing and evaluation of thermal-barrier coatings. MRS Bull. 2012, 37, 911-916. [CrossRef]

25. Levi, C.G.; Hutchinson, J.W.; Vidal-Sétif, M.-H.; Johnson, C.A. Environmental degradation of thermal-barrier coatings by molten deposits. MRS Bull. 2012, 37, 932-941. [CrossRef]

26. Valentine, P.G.; Maier, R.D. Microstructure and Mechanical Properties of Bulk and Plasma-Sprayed $Y_{2} \mathrm{O}_{3}$-Partially Stabilized Zirconia; NASA-CR-165126; Case Western Reserve Univ.: Cleveland, OH, USA, 1980; pp. 1-45.

27. Lanteri, V.; Heuer, A.H. On the Microstructures resulting from the diffusionless cubic-tetragonal transformation in $\mathrm{ZrO}_{2}-\mathrm{Y}_{2} \mathrm{O}_{3}$ alloys. J. Am. Ceram. Soc. 1986, 69, 258-261. [CrossRef]

28. Lanteri, V.; Heuer, A.H.; Mitchell, T.E. Tetragonal phase in the system $\mathrm{ZrO}_{2}-\mathrm{Y}_{2} \mathrm{O}_{3}$. In Science and Technology of Zirconia II; American Ceramic Society: Westerville, OH, USA, 1985; pp. 118-130.ZrO2-Y2O3. In Science and Technology of Zirconia II; American Ceramic Society: Westerville, OH, USA, 1985; pp. 118-130.

29. Virkar, A.V.; Matsumoto, R.L.K. Ferroelastic domain switching as a toughening mechanism in tetragonal zirconia. J. Am. Ceram. Soc. 1986, 69, 224-226. [CrossRef]

30. Srinivasen, G.; Jeu, J.F.; Kuo, S.Y.; Virkar, A.V. Ferroelastic domain switching in polydomain tetragonal zirconia single crystals. J. Am. Ceram. Soc. 1989, 72, 2098-2103. [CrossRef]

31. Stecura, S. Advanced thermal barrier system bond coatings for use on nickel-, cobalt- and iron-base alloy substrates. Thin Solid Films 1986, 136, 241-256. [CrossRef]

32. Stecura, $\mathrm{S}$. New $\mathrm{ZrO}_{2}-\mathrm{Yb}_{2} \mathrm{O}_{3}$ plasma-sprayed coatings for thermal barrier applications. Thin Solid Films 1987, 150, 15-40. [CrossRef]

33. Witz, G.; Schaudinn, M.; Buecklers, T.; Sopka, J. Development of advanced thermal barrier coatings with improved temperature capability. J. Eng. Gas Turbines Power 2017, 139, 081901. [CrossRef]

(C) 2018 by the authors. Licensee MDPI, Basel, Switzerland. This article is an open access article distributed under the terms and conditions of the Creative Commons Attribution (CC BY) license (http://creativecommons.org/licenses/by/4.0/). 